DOI: 10.4274/tpa.45.252

\title{
Bronşiyolit tanısıyla izlenen küçük çocuklarda RSV sıklı̆ı, klinik ve laboratuvar özellikleri
}

The frequency, clinical and laboratory features of RSV in small children with bronchiolitis

\author{
Sinan Mahir Kayıran, Erhan Paloğlu*, Berkan Gürakan \\ Amerikan Hastanesi Çocuk SağıIğı ve Hastalıkları Bölümü, istanbul, Türkive \\ ${ }^{*}$ Amerikan Hastanesi Klinik Laboratuvar Bölümü, İstanbul, Türkiye
}

\section{Özet}

Amaç: Bu çalışmanın amacı 2008-2009 yıllarında bronşiyolit tanısı alan küçük çocuklarda respiratuvar sinsisyal virüs (RSV) sıklığını, klinik ve laboratuvar özelliklerini incelemek.

Gereç ve Yöntem: Ekim 2008- Mayıs 2009 tarihleri arasında alt solunum yolu enfeksiyonu tanısı alan ve nazofarengeal sürüntü örneğinde RSV antijeni bakılan iki yaşından küçük 79 hastanın dosyaları geriye dönük olarak taranarak klinik ve laboratuvar özellikleri değerlendirildi.

Bulgular: Nazofarengeal salgıda RSV antijeni bakılan 79 hastanın 16'sında (\%20) RSV pozitif saptandı. Bu hastalarda yaş, cinsiyet, ortalama gebelik haftası, anne sütü ile beslenme süresi, vücut ısısı, lökosit sayısı, C-reaktif protein (CRP) düzeyi ve yatırılarak tedavi oranı, RSV negatif hastalardan istatistiksel olarak farklı bulunmadı. Hastalarda RSV enfeksiyonu en sık Aralık ayında saptandı. Respiratuvar sinsisyal virüs enfeksiyonu geçiren bebeklerin yoğun bakım biriminde yatırılarak tedavi oranı RSV negatif hasta grubundan istatistiksel olarak anlamlı derecede yüksek bulundu.

Çıkarımlar: Bronşiyolit tanısıyla izlenen iki yaş altı çocuklarda, RSV sıklığı literatür ile uyumlu olarak \%20 bulundu. Respiratuvar sinsisyal virüs enfeksiyonu hastaneye yatış oranlarını etkilememekle birlikte, RSV pozitif hastalarda solunum desteği ihtiyacı nedeniyle yoğun bakım biriminde tedavi oranının RSV negatif hastalardan yüksek olduğu gözlendi. Bu nedenle bebeklerde ve riskli hasta grubunda RSV enfeksiyonunun ağır seyretmesi erken tanı ve koruyucu tedavinin önemini artırmaktadır. (Türk Ped Arş 2010; 45: 252-6)

Anahtar sözcükler: Alt solunum yolu enfeksiyonu, çocuklar, respiratuvar sinsisyal virüs

\section{Summary}

Aim: The aim of this study was to determine the frequency and of RSV clinical and laboratory features of respiratory syncytial virus (RSV) in small children with bronchiolitis in 2008-2009.

Material and Method: A total of 79 children younger than two years of age with bronchiolitis at whom RSV antigen was analyzed in the nasopharengeal secretion between October 2008-May 2009 were evaluated from clinical charts retrospectively.

Results: Respiratory syncytial virus antigen in nasopharengeal secretions was positive in 16 (\%20) of 79 patients. The age, sex, mean gestational week, duration of breast feeding, fever, mean leukocyte count, C-reactive protein (CRP) level and hospitalization rate were not significantly different between the RSV positive and negative patients. Respiratory syncytial virus infection was frequently detected in December. Intensive care unit admission for advanced respiratory support was found significantly higher in the RSV positive patients.

Conclusions: Respiratory syncytial virus incidence in children younger than two years-old with the diagnosis of bronchiolitis was $\% 20$, concordant with the literature. Although hospitalization rate of RSV positive and negatif patients is similar, intensive care unit admission for advanced respiratory support was significantly higher in RSV positive patients. Therefore, as RSV infection in infants and high risk patients has a severe clinical course, this situation increases the importance of early diagnosis and prophylaxis. (Turk Arch Ped 2010; 45: 252-6)

Key words: Children, lower respiratory tract infection, respiratory syncytial virus

Yazışma Adresi/Address for Correspondence: Sinan Mahir Kayıran, Amerikan Hastanesi Çocuk Sağlığı ve Hastalıkları Bölümü, Güzelbahçe Sok. No:20 Şişli, İstanbul, Türkiye E-posta: sinanmahir@gmail.com Geliş Tarihi/Received: 19.10.2009 Kabul Tarihi/Accepted: 12.04.2010 


\section{Giriş}

Respiratuvar sinsisyal virüs (RSV) solunum yollarının silyalı epitel hücrelerini tutan paramiksovirüs ailesinden bir RNA virüsü olup, bebeklerde ve küçük çocuklarda pnömoni ve bronşiyolit gibi viral alt solunum yolu enfeksiyonunun (ASYE) en önemli nedenidir (1). İki yaşına kadar bütün çocukların en az bir defa RSV enfeksiyonu geçirdiği, \%1020 'sinin ise birden çok defa virüsle enfekte olduğu bildirilmektedir (2). Ülkemizde solunum yolları enfeksiyonlarında RSV sıklığı değișik çalıșmalarda \%11-51 oranında bildirilmektedir (3-6). Virüs, büyük parçalı damlacıklar ve salgılarla doğrudan temas sonucu bulaşır. Ateş, burun akıntısı, öksürük ile belirgin üst solunum yolu enfeksiyonu bulgularıyla başlayan hastalık, büyük çocuklarda ve erişkinlerde üst hava yollarında sınırı kalırken, küçük çocuklarda özellikle altı aydan küçük bebeklerde sıklıkla bronşiyolit veya pnömoni gibi ASYE olarak sonuçlanır (7).

Respiratuvar sinsisyal virüse bağlı hastalık sıklığı mevsimsel özellik gösterir. Ülkemizde yapılan çalışmalarda Aralık ve Ocak aylarında en sık olmak üzere Kasım-Nisan ayları arasında görüldüğü bildirilmiştir $(5,8)$. Erken doğmuş bebekler, doğuştan kalp hastaları, bronkopulmoner displazi ve kistik fibroz gibi kronik akciğer hastalıkları veya immün yetersizliği olan bebekler ağır enfeksiyon açısından risk grubunu oluşturmaktadır (1). Altı aydan küçük bebekler, Nisan-Ekim aylarında doğanlar, kalabalık yaşam koşulları, çocuk yuvalarında bakım, düşük sosyoekonomik düzey, okula giden kardeş varlığı, sigara dumanına maruz kalma, ailede astım atopi öyküsü ve anne sütü ile beslenememe RSV enfeksiyonu açısından diğer risk etmenleridir $(9,10)$. Hastalık döneminde nazofarengeal salgıda antijen saptanması önerilen tanı yöntemidir. Bebeklerde virüsün yayılımı daha uzun ve yoğun olduğu için bu test erişkinlere göre daha duyarlıdır (1). Viral kültür kullanımı pratik değildir. Respiratuvar sinsisyal virüs enfeksiyonunda tedavide esas olan solunum desteği ve hidrasyondur (11). Respiratuvar sinsisyal virüsün etkili tedavisinin ve aşısının olmaması nedeniyle, RSV enfeksiyonlarından korunmak için riskli hasta grubuna RSV IVIG (Respigam) ve RSV monoklonal antikorlar (Palivizumab-Synagis) ile koruma önerilmektedir $(12,13)$.

Bu çalışmada, bronşiyolit tanısı alan hastalarımızda etiolojide RSV'nin sıklığı, klinik ve laboratuvar özellikleri literatürle birlikte değerlendirilmiştir.

\section{Gereç ve Yöntem}

Ekim 2008- Mayıs 2009 tarihleri arasında Çocuk Polikliniği, Çocuk Servisi ve Yoğun Bakım Birimi'nde ASYE tanısıyla izlenen toplam 422 hastadan, nazofarengeal salgı örneğinde RSV incelemesi yapılan olguların dosyaları geriye dönük olarak incelendi ve iki yaşından küçük 79 bronşiyo- litli çocuk çalışma kapsamına alındı. Ateş, öksürük, hıııtı, hışıltı, morarma ve nefes almada güçlük yakınmalarıyla getirilen hastalar, fizik muayenesinde ekspiryum uzunluğu, kaba sesler saptanması, röntgen bulguları ile bronşiyolit tanısı aldı.

Hastaların yaş, cinsiyet, gebelik haftaları, başvurduğu ay, anne sütü ile beslenme süresi, ailede atopi öyküsü, vücut ISISI, hastaneye yatıııldıysa yatış süresi, solunum desteği gereksinimi ve laboratuvar sonuçları hasta dosyalarından öğrenildi. Klinik ve laboratuvar bulguları viral enfeksiyon düşündüren hastalardan RSV tetkiki istenmiş olduğu gözlendi. Bakteriyel enfeksiyonu kanıtlanmış olgular çalışmaya alınmadı. Hastaların hiçbirinde önceden RSV'ye karşı koruyucu tedavi uygulanmamıştı.

Hastalardan RSV testi için örnekler nazofarengeal sürüntü, nazofarengeal yıkama veya kapalı sistem nazofarengeal aspirasyon ile alındı. Nazofarengeal salgı örnekleri 30-60 dakika içerisinde Mikrobiyoloji Laboratuvarı'nda hızı immünokromotografik membran yöntemi ile (Binax NOW RSV) çalışıldı. Kitlerin her çalışma döneminde pozitif ve negatif kontrollerinin doğrulanması sonrası hasta sonuçları değerlendirildi. Çalışma sonucunda elde edilen veriler değerlendirilirken istatistiksel analizler için SPSS 17.0 programı kullanıldı.

Veriler ortalama $\pm S S$ (standart sapma) olarak sunuldu. Niteliksel veriler ki-kare testi ve student $t$ testi ile karşılaştırıld. İstatistiksel anlamlıık $\mathrm{p}<0,05$ olarak belirlendi.

\section{Bulgular}

İki yaşından küçük 38 kız, 41 erkek toplam 79 hasta çaışmaya alındı. Hastaların 16'sında (\%20) RSV pozitif bulundu. Respiratuvar sinsisyal virüs pozitif hastaların 7'si kız, 9'u erkek, RSV negatif hastaların 31'i kız, 32'si erkek idi. Çalışma grubunda, 27-32. gebelik haftasında doğan yedi hastanın üçünde ve 33-35. gebelik haftasında doğan altı hastanın üçünde olmak üzere 36 . gebelik haftasından erken doğan 13 bebeğin altısında RSV enfeksiyonu bulundu. Respiratuvar sinsisyal virüs pozitif hastaların ortalama yaşı $4,2 \pm 2,05$ ay, ortalama gebelik yaşı $35,44 \pm 4,2$ hafta, RSV negatif hastaların ortalama yaşı $6,9 \pm 5,3$ ay, ortalama gebelik yaşı $37,4 \pm 2,7$ hafta bulundu (Tablo 1 ). Respiratuvar sinsisyal virüs pozitif hasta grubunda ortalama yaş ve gebelik haftası negatif gruba göre küçük olmakla birlikte bu fark istatistiksel olarak anlamlı bulunmadı $(p>0,05)$.

Ekim ayından Mayıs ayına kadar her ay sırayla 1, 2, 28, $25,13,3$ ve 7 hasta görüldü. Aralık ayında başvuran 28 hastanın 10'unda, Ocak, Şubat ve Nisan aylarında başvuranların ikisinde RSV enfeksiyonu saptandı (Şekil 1).

Ortalama anne sütü ile beslenme süresi RSV pozitif grupta $3,56 \pm 2,1$ ay, RSV negatif grupta $4,0 \pm 2,5$ ay , yatırılarak tedavi edilen hastalarda $3,88 \pm 2,5$ ay, ayaktan izlenen hastalarda ise $4,00 \pm 2,2$ ay idi. 
Çalışma grubundaki hastalarda muayene sonucunda RSV pozitif iki, negatif üç hastada orta kulak iltihabı tespit edildi. Respiratuvar sinsisyal virüs pozitif hastaların ikisinde $(\% 12,5)$, negatif hastaların 11 'inde $(\% 17,4)$ ailede astım-atopi öyküsü vardı.

Başvuru anında ortalama vücut ISISI, RSV pozitif grupta $37,31 \pm 0,7 \mathrm{C}^{\circ}$, RSV negatif grupta $37,38 \pm 0,6 \mathrm{C}^{\circ}$ olarak ölçüldü. Respiratuvar sinsisyal virüs pozitif hastaların 9'unda, negatif hastaların 50'sinde tam kan sayımı ve serum C-reaktif protein (CRP) değerlendirilmesi yapıldı. Respiratuvar sinsisyal virüs pozitif grubun ortalama lökosit sayısı $10285 \pm 3375 / \mathrm{mm}^{3}$, CRP düzeyi $6,67 \pm 5,43 \mathrm{mg} / \mathrm{L}$, RSV negatif grubun ortalama lökosit sayısı $10103 \pm 3$ 925/ $\mathrm{mm}^{3}$, CRP düzeyi 10,80 $\pm 23,79 \mathrm{mg} / \mathrm{L}$ bulundu. Ortalama lökosit sayısı ve CRP düzeyleri gruplar arasında farkllık göstermedi $(p>0,05)$.

Klinik olarak altı $(\% 7,5)$ hasta pnömoni + bronşiyolit, $73(\% 92,5)$ hasta ise bronşiyolit tanısıyla izlendi. Respiratuvar sinsisyal virüs pozitif grupta 12 (\%75), RSV negatif grupta ise $47(\% 74,6)$ hastanın yatırılarak tedavi edildiği görüldü. Pnömoni tanısı alan hastaların hepsi yatırılarak tedavi edildi. Yatıs süresi RSV pozitif grupta $6,87 \pm 11,91$ gün, negatif grupta $3 \pm 2,8$ gün bulundu. Yatış oranları ve yatış süresi açısından RSV pozitif ve negatif hastalar arasında istatistiksel anlamlı farklılık bulunmadı $(p>0,05)$. Respiratuvar sinsisyal virüs pozitif grupta dört (\%25), negatif grupta da dört $(\% 6,3)$ hasta ileri solunum desteğine intiyaç duyduğu için yoğun bakım birimine yatıııdı. Bu hastaların tamamı üç aydan küçük bebeklerdi. Respiratuvar sinsisyal virüs pozitif hastalarda yoğun bakım birimine yatış oranı istatistiksel olarak anlamlı düzeyde yüksek bulundu $(p<0,05)$.

\section{Tartışma}

$\mathrm{Bu}$ çalışmada bronşiyolit tanısı alan hastalarımızın $\% 20$ 'sinde RSV enfeksiyonu pozitif bulundu. Bu oran ülkemizden daha önce bildirilen yayınlarla uyumludur (3-6).

Solunum yolu salgılarında viral etkenin kültürde üretilmesi RSV tanısında altın ölçüt kabul edilmesine rağmen virüsün aşırı duyarlıı̆ı ve yavaş üremesi gibi nedenlerle normalde kullanılmamaktadır. Respiratuvar sinsisyal virüs IgM antikorlarının, hastalık bulguları başladıktan 5-8 gün sonra oluşması ve hastalığın başlangıç döneminde kanda saptanmaması sebebiyle tanı amaçlı antikor bakılması da önerilmez (6). Nazofarengeal salgıda virüs antijen tespiti hızlı tanı sağlaması nedeniyle özellikle RSV sezonunda küçük çocuklarda sık kullanılan yöntemdir. Çalışmamızda kullanılan Binax NOW RSV kitleri beș yaș altı çocukların burun salgı örneklerinde RSV füzyon proteininin saptanmasında kullanılması FDA (Food and Drug Administration) tarafından da

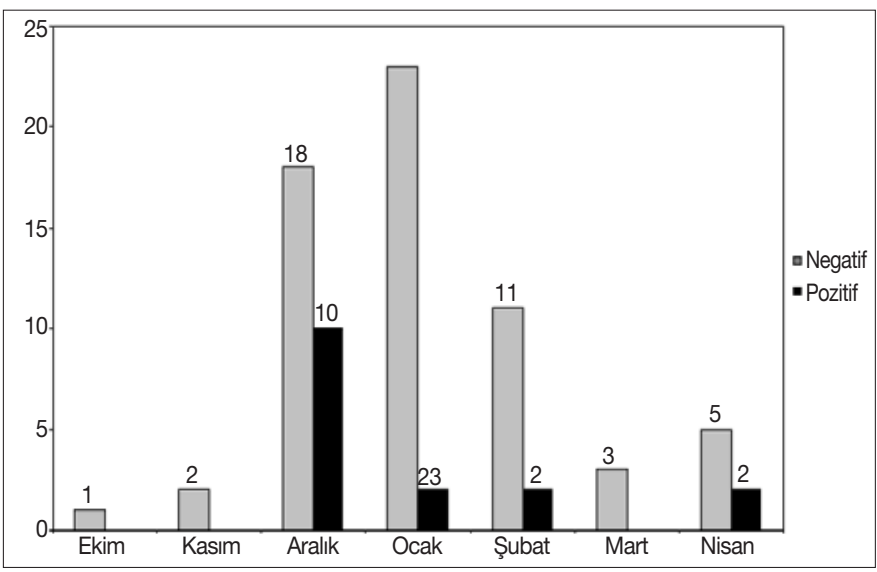

Şekil 1. Respiratuvar sinsisyal virüs pozitif ve negatif hastaların aylara göre dağılımı

Tablo 1. Respiratuvar sinsisyal virüs pozitif ve negatif hastaların sosyodemografik özellikleri ve laboratuvar bulgularına göre karşılaştırılması*

\begin{tabular}{|c|c|c|c|}
\hline & $\begin{array}{c}\text { RSV (+) } \\
(n=16)\end{array}$ & $\begin{array}{c}\text { RSV (-) } \\
(n=63)\end{array}$ & $\mathbf{p}$ \\
\hline Yaş (ay) & $4,2 \pm 2,05$ & $6,9 \pm 5,3$ & 0,439 \\
\hline \multicolumn{4}{|l|}{ Cinsiyet } \\
\hline Kız, n (\%) & $7(\% 44)$ & $31(\% 49)$ & 0,696 \\
\hline Erkek, n (\%) & $9(\% 56)$ & $32(\% 51)$ & \\
\hline Gebelik haftası & $35,44 \pm 4,2$ & $37,4 \pm 2,7$ & 0,261 \\
\hline Anne sütü ile beslenme süresi (ay) & $3,56 \pm 2,1$ & $4,0 \pm 2,5$ & 0,214 \\
\hline Lökosit sayısı $\left(/ \mathrm{mm}^{3}\right)$ & $10285 \pm 3375$ & $10103 \pm 3925$ & 0,266 \\
\hline $\mathrm{CRP}(\mathrm{mg} / \mathrm{L})$ & $6,67 \pm 5,43$ & $10,80 \pm 23,79$ & 0,130 \\
\hline Yatan hasta sayısı, n (\%) & $12(75)$ & $47(74,6)$ & 0,974 \\
\hline Yatış süresi (gün) & $6,87 \pm 11,91$ & $3 \pm 2,8$ & 0,366 \\
\hline Yoğun bakım ileri solunum desteği, n (\%) & $4(25)$ & $4(6,3)$ & 0,027 \\
\hline
\end{tabular}

- Değerler ortalama \pm SS olarak verilmiștir

- RSV: Respiratuvar sinsisyal virüs 
önerilen hızlı antijen testidir. Testin duyarlılı̆ı \%78,9-90, özgüllüğü \%100 olarak bildirilmiştir $(14,15)$.

Respiratuvar sinsisyal virüs enfeksiyonunda erkek cinsiyet ve anne sütü ile beslenememe çevresel risk etmenleri olarak bildirilmektedir (16-18). Oddy ve ark.ları (19) çalışmalarında ilk iki ay sadece anne sütü ve altıncı ayda halen anne sütü ile beslenmenin alt solunum yolu enfeksiyonları sıklığı ve hastalanma oranını azalttığını bildirmiştir. Çalışmamızda erkek ve kız bebeklerde RSV pozitifliği, hastaneye yatış oranları ve yoğun bakımda ileri solunum desteği gereksinimi açısından farklılık bulunmadı. Ortalama anne sütü ile beslenme süresinin RSV enfeksiyonu geçiren hastalarda ve yatırılarak tedavi edilen hastalarda daha kısa olması bu bilgiler ile uyumlu olmakla birlikte, istatistiksel olarak anlamlı fark bulunmadı.

Çalışmamızda RSV enfeksiyonu geçiren hastaların ortalama gebelik haftası istatistiksel olarak anlamlı olmamakla birlikte düşük bulundu. Otuz altıncı gebelik haftasından erken doğan 13 hastanın altısında RSV enfeksiyonu saptandı. Otuz ikinci gebelik haftasından önce doğan bebeklerin RSV enfeksiyonundan korunmasında humanize bir monoklonal antikor olan palivizumab ile koruma önerilmektedir (12). Otuz üç-35 gebelik haftasında doğan bebeklerde palivizumab uygulaması önerilmemekle birlikte diğer çevresel etmenlerin etkinliğinin araştırılmasıyla bu haftalarda doğan bebeklerde de yüksek risk grubu tanımlanmaya çalıșılmaktadır $(12,20,21)$.

Ülkemizde virüs sıklıkla Aralık ve Ocak aylarında olmak üzere Ekim- Mart ayları arasında hastalık yapar $(6,22)$. Bu tespit ile uyumlu olarak hastanemizde bronşiyolit tanısıyla takip olan hastalarımızda en sık Aralık ayında olmak üzere Aralık-Nisan ayları arasında RSV pozitifliği saptandı (Şekil 1).

Yaşamın ilk yıllarında RSV enfeksiyonu geçiren çocuklarda tekrarlayan hışıltı atakları ve astımın daha sık olduğunu gösteren çalışmalar vardır $(23,24)$. Bu çocuklarda atopide artış bulunmamıştır. Viral enfeksiyonlar sonrası hava yollarında geçici aşırı duyarlılık olmakla birlikte atopik yatkınlığı olan çocuklarda astım geliştiği düşünülmektedir (25). Valkonen $\mathrm{H}$. ve ark.'ları (26) ise tekrarlayan hışוltı ataklarının RSV bronşiyoliti sonrası RSV dışı virüs enfeksiyonlarından daha sık olmadığını göstermiştir. Çalışmamızda bronșiyolit tanısı alan RSV pozitif ve negatif hastalar arasında atopi açısından fark görülmedi.

Respiratuvar sinsisyal virüs enfeksiyonunda orta kulak iltihabı gelişebilmekte ve bu oran \%30'a kadar çıkabilmektedir (27). Çalıșmamızda RSV enfeksiyonu tespit edilen bronşiyolit olgularının ikisinde $(\% 12,5)$ orta kulak iltihabı saptanmıştır.

Respiratuvar sinsisyal virüs pozitif ve negatif hasta grupları arasında başvuru anında ateş, lökosit sayısı, CRP değerleri, hastaneye yatış oranları ve yatış süresi açısından fark görülmedi $(p>0,05)$. Respiratuvar sinsisyal virüs enfeksiyonu geçiren dört (\%25) hasta ileri solunum desteği için yoğun bakım birimine yatıııldı. Yoğun bakım birimine RSV enfeksiyonu nedeniyle yatırılan bebeklerin incelendiği bir çalıșmada ölüm oranının \%8,6 olduğu ve bu hastaların \%29'unda kromozomal anomali, \%27'sinde kalp malformasyonu, \%15'inde nöromüsküler hastalık, \%12'sinde kronik akciğer hastalığı, \%9'unda havayolu anomalisi, \%9'unda immün yetersizliğin olduğu ve eşlik eden durumların ölümü anlamlı olarak arttırdığı bildirilmiştir (28). Çalışma grubumuzda yoğun bakım biriminde tedavi edilen hastalardan birinde bronkopulmoner displazi mevcuttu, kaybedilen hastamız olmadı.

Sonuç olarak çalışmamızda anne sütü ile beslenme süresi ve cinsiyetin hastalığın seyrini etkilemediğini, RSV enfeksiyonu geçiren hasta grubunda yaș ve gebelik haftasının daha küçük olduğunu gördük. Respiratuvar sinsisyal virüs pozitif olgular RSV negatif olgularla karşılaştııılığında hastaneye yatış oranı her iki hasta grubunda aynı olmakla birlikte, ileri solunum desteği amacıyla yoğun bakım birimine yatış oranı RSV pozitif hastalarda anlamlı derecede yüksek bulundu. Bu nedenle bebeklerde ve özellikle riskli hasta grubunda RSV enfeksiyonunun ağır seyretmesi erken tanı ve koruyucu tedavinin önemini artırmaktadır.

\section{Kaynaklar}

1. Black CP. Systematic review of the biology and medical management of respiratory syncytial virus infection. Respir Care 2003; 48: 209-31. Aabstract/ PDD

2. Mcintosh K. Respiratory syncytial virus. In: Behrman RE, Kliegman RM (eds). Nelson Textbook of Pediatrics. 18. edition. Philadelphia: WB Saunders, 2007: 1388-90.

3. Yilmaz G, Uzel N, Isik N, Baysal SU, Aslan S, Badur S. Viral lower respiratory tract infections in children in Istanbul, Turkey. Pediatr Infect Dis J 1999; 18: 173. Abstract

4. Kanra G, Tezcan S, Yilmaz G. Turkish National Respiratory Syncytial Virus (RSV) Team. Respiratory syncytial virus epidemiology in Turkey. Turk J Pediatr 2005; 47: 303-8. Abstract/ Full Tex / PDA

5. Hatipoğlu S, Arıca S, Çelik Y, Öztora S, ŞevketoğluE, Erkum T. Alt solunum yolu enfeksiyonu tanısıyla hastanemize yatıılan olgularda RSV enfeksiyonu sıklığı ve klinik özellikleri. Düzce Tıp Dergisi 2009; 11: 38-44. IPDH

6. Hacımustafaoğlu M, Çelebi S, Aynacı E, Köksal N, Sınırtaş M, Göral G. Evaluation of RSV frequency in acute bronchiolitis by different methods. Çocuk Enf Derg 2008; 4: 156-61. Abstract / Full Tex / PDA

7. American Academy of Pediatrics Committee on Infectious Diseases. In: Peter G (ed). 1997 Red Book: Report of the Committee on Infectious Diseases. 24th edition. Elk Grove Village, Illinois: American Academy of Pediatrics, 1976; 89: 11-15.

8. Hacımustafaoğlu M. RSV İnfeksiyonları. ANKEM Derg 2006; 20: 240-7. PDA

9. Law BJ, Carbonell-Estrany X, Simoes EA. An update on respiratory syncytial virus epidemiology: a developed country perspective. Respir Med 2002; 96 Suppl B: S1-7. Abstract / [PDA

10. Figueras-Aloy J, Carbonell-Estrany X, Quero J; IRIS Study Group. Case-control study of the risk factors linked to respiratory syncytial virus infection requiring hospitalization in premature infants born at a gestational age of 33-35 weeks in Spain. Pediatr Infect Dis J 2004; 23: 815-20. (Abstract)

11. American Academy of Pediatrics Subcommittee on Diagnosis and Management of Bronchiolitis. Diagnosis and management of bronchiolitis. Pediatrics 2006; 118: 1774-93. Abstract / Full

\section{Tex/ (PDF)}

12. Comittee on infectıous diseases. Policy statement-modified recommendations for use of palivizumab for prevention of respiratory syncytial virus infections. Pediatrics 2009; 124; 2345-55. 
13. Morris SK, Dzolganovski B, Beyene J, Sung L. A meta-analysis of the effect of antibody therapy for the prevention of severe respiratory syncytial virus infection. BMC Infect Dis 2009; 9:106-25. Abstract / Full Tex / PDA

14. Jonathan N. Diagnostic utility of BINAX NOW RSV-an evaluation of the diagnostic performance of BINAX NOW RSV in comparison with cell culture and direct immunofluorescence. Ann Clin Microbiol Antimicrob 2006; 5:13-8. [Abstract / Eull Text]/ PDA

15. Selvarangan $R$, Abel $D$, Hamilton $M$. Comparison of $B D$ Directigen EZ RSV and Binax NOW RSV tests for rapid detection of respiratory syncytial virus from nasopharyngeal aspirates in a pediatric population. Diagn Microbiol Infect Dis 2008; 62: 157-61. [Abstract) / Eull Tex / PDH

16. Simoes EA. RSV disease in the pediatric population: epidemiology, seasonal variability, and long-term outcomes. Manag Care 2008; 17: 3-6. (Abstract)

17. Doering G, Gusenleitner W, Belohradsky BH, Burdach S, Resch B, Liese JG. The risk of respiratory syncytial virus-related hospitalizations in preterm infants of 29 to 35 weeks gestational age. Pediatr Infect Dis J 2006; 25: 1188-90. (Abstract)

18. Damore D, Mansbach JM, Clark S, Ramundo M, Camargo CA Jr. Prospective multicenter bronchiolitis study: predicting intensive care unit admissions. Acad Emerg Med 2008; 15: 887-94. Abstract)/(Full Text) / (PDD)

19. Oddy $\mathrm{WH}$, Sly PD, de Klerk $\mathrm{NH}$, et al. Breast feeding and respiratory morbidity in infancy: a birth cohort study. Arch Dis Child 2003; 88: 224-8. Aabstract / PDA

20. Simões EA, Carbonell-Estrany X, Fullarton JR, et al. A predictive model for respiratory syncytial virus (RSV) hospitalisation of premature infants born at 33-35 weeks of gestational age, based on data from the Spanish FLIP Study. Respir Res 2008; 9: 78-88. [Abstrac) / (Full Tex] / PDH
21. Paes B, Steele S, Janes M, Pinelli J. Risk-Scoring Tool for respiratory syncytial virus prophylaxis in premature infants born at 33-35 completed weeks' gestational age in Canada. Curr Med Res Opin 2009; 25: 1585-91. [Abstract/ (Full Tex/[PDF)

22. Erten $M$, Karayağar $N$, Ergüven $M$, ve ark. Bronşiyolitli olgularımızda respiratuvar sinsisyal virüs (RSV) infeksiyonu sıklığının değerlendirilmesi. Göztepe Tıp Dergisi 2006; 21:113-5. Abstract

23. Sigurs N, Gustafsson PM, Bjarnason R, et al. Severe respiratory syncytial virus bronchiolitis in infancy and asthma and allergy at age 13. Am J Respir Crit Care Med 2005; 171: 137-41. Abstract / Full Tex / PDF

24. Henderson J, Hilliard TN, Sherriff A, Stalker D, AI Shammari N, Thomas HM. Hospitalization for RSV bronchiolitis before 12 months of age and subsequent asthma, atopy and wheeze: a longitudinal birth cohort study. Pediatr Allergy Immunol 2005; 16: 386-92. [Abstract/ Eull Text/ (PD)

25. Kneyber MCJ, Steyerberg EW, de Groot R, Moll HA. Long-term effects of respiratory syncytial virus (RSV) bronchiolitis in infants and young children: a quantitative review. Acta Paediatr 2000; 89: 654-60. Abstrac//(PDF)

26. Valkonen $\mathrm{H}$, Waris M, Ruohola A, Ruuskanen O, Heikkinen $\mathrm{T}$. Recurrent wheezing after respiratory syncytial virus or non-respiratory syncytial virus bronchiolitis in infancy: a 3-year follow-up. Allergy 2009; 64: 1359-65. Abstract/ Full Tex / PDH

27. Simoes EA, Groothuis JR, Tristram DA, et al. Respiratory syncytial virus-enriched globulin for the prevention of acute otitis media in high risk children. J Pediatr 1996; 129: 214-9. (Abstract) / Full Tex / PDF

28. Thorburn K. Pre-existing disease is associated with a significantly higher risk of death in severe respiratory syncytial virus infection. Arch Dis Child 2009; 94: 99-103. Abstract 